\title{
Mental health in children and adolescents: vision of the professionals on challenges and possibilities in building up intersectoral networks
}

\author{
Saúde mental infantojuvenil: visão dos profissionais sobre desafios \\ e possibilidades na construção de redes intersetoriais \\ Salud mental infanto-juvenil: la visión de los profesionales sobre las \\ posibilidades y los desafíos en la construcción de redes intersectoriales
}

\section{Cristiane Kenes Nunes ${ }^{a}$ \\ Agnes Olschowsky ${ }^{a}$ \\ Aline Basso da Silva ${ }^{a}$ \\ Luciane Prado Kantorski ${ }^{b}$ \\ Valéria Cristina Christello Coimbrab}

\begin{abstract}
How to cite this article: Nunes CK, Olschowsky A, Silva AB, Kantorski LP, Coimbra VCC. Mental health in children and adolescents: vision of the professionals on challenges and possibilities in building up intersectoral networks. Rev Gaúcha Enferm. 2019;40:e20180432. doi: https://doi.org/10.1590/19831447.2019.20180432
\end{abstract}

a Universidade Federal do Rio Grande do Sul (UFRGS), Escola de Enfermagem, Programa de Pós-Graduação em Enfermagem. Porto Alegre, Rio Grande do Sul, Brasil.

- Universidade Federal de Pelotas (UFPel), Faculdade de Enfermagem, Programa de Pós-Graduação em Enfermagem. Pelotas, Rio Grande do Sul, Brasil.

\section{ABSTRACT}

Objective: To analyze the possibilities and challenges in building intersectoral networks in mental health in the professional's view involved in the care for children and adolescents treated at the Child and Adolescent Psychosocial Care Center.

Methods: A qualitative, descriptive and exploratory research, held from May to June 2014, performed a town in southern Brazil. Data were collected through semi-structured interviews with 26 workers intersectoral networking and submitted to thematic analysis.

Results: The articulation of different services and intersectoral care devices, and challenges to be overcome, the individual treatment plan, social policies that realize the real needs of users, including family and the medical-hegemonic model, were pointed out as possibilities.

Conclusion: The care raised to the intersectoral level is a necessity and a way to achieve new perspectives on care and its articulations to consolidate the Child and Adolescent Mental Health policy.

Keywords: Intersectoral collaboration. Mental health. Child. Adolescent. Public policy.

\section{RESUMO}

Objetivo: Analisar as possibilidades e desafios na construção de redes intersetoriais em saúde mental na visão dos profissionais envolvidos no cuidado a crianças e adolescentes atendidos no Centro de Atenção Psicossocial Infantojuvenil.

Metodologia: Pesquisa qualitativa, descritiva e exploratória, realizada no período de maio a junho de 2014, em um município do Sul do Brasil. Os dados foram coletados por meio de entrevistas semiestruturada com 26 trabalhadores da rede intersetorial e submetidos à análise temática.

Resultados: Apontaram-se como possibilidades a articulação de diferentes serviços e dispositivos de cuidado intersetorial, e desafios a serem superados, o plano terapêutico singular, as políticas sociais que percebem as reais necessidades dos usuários, a inclusão da família e o modelo médico-hegemônico.

Conclusões: 0 cuidado elevado ao plano intersetorial é uma necessidade e um modo de lograr novos olhares sobre o cuidado e suas articulaç̧ões para consolidação da política de Saúde Mental da Criança e Adolescente.

Palavras chave: Colaboração intersetorial. Saúde mental. Criança. Adolescente. Política pública.

\section{RESUMEN}

Objetivo: Cnalizar las posibilidades y los desafíos en la construcción de redes intersectoriales en salud mental, según la opinión de los profesionales involucrados en el cuidado de niños y adolescentes atendidos en el Centro de Atención Psicosocial para Niños y Adolescentes.

Métodos: Investigación cualitativa, descriptiva y exploratoria, realizada en el período de mayo a junio de 2014, en una ciudad en el sur de Brasil. Se recolectaron los datos por medio de entrevistas semiestructuradas con 26 trabajadores de redes intersectoriales y luego se los sometieron al análisis temático.

Resultados: Se apuntaron como posibilidades la articulación de los diferentes servicios y dispositivos de atención intersectoriales, y los desafíos a superar, el plan de tratamiento individual, las políticas sociales que dan cuenta de las necesidades reales de los usuarios, incluyendo la familia y el modelo médico-hegemónico.

Conclusión: El cuidado elevado al plan intersectorial es una necesidad y un modo de lograr nuevas miradas sobre el cuidado y sus articulaciones para consolidar la política de Salud Mental del Niño y del Adolescente.

Palabras clave: Colaboración intersectorial. Salud mental. Niño. Adolescente. Política pública. 


\section{口INTRODUCTION}

In the field of mental health, the child and adolescent population remained in the background for many years, compared to initiatives related to adult population care. However, from State initiatives, new legislations, social mobilizations and political mobilizations, the need to think about ensuring the protection of children and adolescents was made visible. The Child and Adolescent Statute (CAS) is an important political landmark that has propitiated the development of several actions reaffirming the importance for restructuring the public care policies for this population ${ }^{(1)}$.

In this sense, children and adolescents who need care in mental health should have access to the different levels of complexity and devices that make up the care network, articulated in an intersectoral network, to ensure comprehensive care and produce a better response to the different orders and problems involved in care and treatment ${ }^{(2)}$.

In this direction, the intersectorality herein is based on the articulation between people and diverse sectors, allowing, therefore, integrating knowledge, and sharing joint actions, diverse powers and wills. It is betting on the power of collective outputs, producing a new way of working and building up public policies ${ }^{(3)}$.

And to think of this network beyond a set of services, actions or interventions, that work efficiently, it is necessary to break the segmentation and perceive the network as a woven project among many "nodes" that make up an articulated collective capable of producing flows that enhance the care, attention and life ${ }^{(4)}$.

One of the services that make up this network is the Child and Adolescent Psychosocial Care Center (CAPCC), defined as a territorial base service and computer network, designed to meet the demands of childhood and adolescence, under the psychosocial care logic. Since CAPCC works with an interdisciplinary team and together with other devices in the territory, these services represent the main strategy for building up the care network, responding to the care for cases of intense suffering and organizing the other mental health demands of the assigned territory ${ }^{(5)}$. In this regard, it is also important to point out, according to Ordinance 3.088, dated December 23, 2011, of the Ministry of Health, which settles the Psychosocial Care Network (PCN) for people suffering from or having a mental disorder arising from addiction to drugs, including children and adolescents, that the care actions happen in an expanded way from the interlocution between the different attention points in the network.

Given such facts, intersectoral actions in the care of children and adolescents, should be thought of in all places of life for the user, not restricted to an institution. That is, they must go beyond the limits of the physical structure and be articulated with the spheres that intersect the life of the subject, seeking resources in the territory, and more, include in their scope interdisciplinary work, communication among several points of the network, in a permanent dialogue process, among the various available services and resources( ${ }^{(6)}$.

Among the existing research on children's mental health, there is little mention to the construction of user-based care networks in healthcare services and other sectors. However, some studies have paid attention to the potentialities and weaknesses in the care network construction, stressing the incorporation of articulated psychic suffering into network services and actions, as well as pointing out to the commitment of intersectoral collaboration and community participation ${ }^{(7-8)}$.

In this sense, it is important to pay attention to the intersectoral actions carried out between the CAPCC and the devices that make up the care network that care for children and adolescents. The possibilities of collective constructions, which observe that the child and the adolescent need to be thought of in various aspects of their experiences, life histories, biological, social, cultural, leisure, education and care needs.

It is argued that this analysis may contribute to the broader discussion about the role of mental health services and other devices that make up the care network for this public, reflecting on the possibilities and challenges in the construction of actions that are more coherent with the mental health policies for children and adolescents.

Therefore, this article shows the following guiding question: What are the possibilities and challenges in the construction of intersectoral networks in mental health for the care of children and adolescents treated at the Child and Adolescent Psychosocial Care Center (CAPCC)? The following objective was formulated to answer this question: to analyze the possibilities and challenges in the construction of intersectoral networks in mental health in the perspective of the professionals involved in the care of children and adolescents treated at the Child and Adolescent Psychosocial Care Center (CAPCC).

\section{METHOD}

A qualitative, descriptive and exploratory methodology study, carried out in the first half of 2014, in a city in the South of Rio Grande do Sul, Brazil.

The qualitative research offers the possibility to analyze and understand the complex phenomena. In this way, to understand is to exercise the capacity to put oneself in 
the place of the other, considering that as a human being one can exercise this understanding. In order to realize the understanding, it is necessary to take the singularities and subjectivities in the individual into account, as well as their experiences, life histories, worldviews, and relations within the collective history of the group and the context to which they belong ${ }^{(9)}$. The qualitative research was chosen to promote listening and understanding of the construction of intersectoral networks, since we evaluated through testimonies, dialogues and relationships, the possibility of making contact with the reality in the articulations, emblematic communications of network cares.

Twenty-six professionals took part in this study involved in the intersectoral network, such as the Guardianship Council, Public Prosecutor's Office, Courts and Judges of Childhood and Adolescence, Basic Health Unit, Hospital, Social Assistance Referral Center (SARC), Specialized Reference Center for Social Assistance (SRCSA), Shelter and Schools involved in the care of children and adolescents who are cared in the CAPCC. Empirical data collect was performed using a semi-structured interview.

The semi-structured interview combines closed and open questions, where the interviewee has the possibility to discuss a topic, without losing the formulated questioning, obeying a script previously established by the researcher. This approach enables the researcher to have a better social interaction and exploration of issues relevant to the study ${ }^{(9)}$.

In order to carry out information's production, a previous contact was made with the participants, checking the best time for the interviews to be carried out in the professionals' workplace, with an average duration of 25 minutes, later to be fully recorded in audio and transcribed. The roadmap covered the following issues: How is the network of mental health for children and adolescents organized beyond the health system? What are the intersectoral actions developed, as well as the possibilities and the challenges?

The professionals working in the intersectoral network for at least six months were considered for the inclusion criterion, and the professionals who, at the time of producing and recording the information, were excluded from service by medical certificate, leave or vacation were excluded. Data analysis was done through the exhaustive reading of all the interviews, until the material was properly saturated. Submission of the testimonies was identified by the letters PR, representing the Professional, followed by the Arabic number corresponding to the order in the interview.

The information was analyzed adopting the technique of analysis, in the thematic modality ${ }^{(9)}$, obeying three stages consisting in: pre-analysis, exploitation of the material and data treatment. In the first stage, a floating reading of the material was performed, choosing the materials to be studied and analyzed, constituting the corpus of analysis, which is about the organization of the material and formulation of hypotheses and objectives. The second stage was dedicated to exploring the material, in the data meeting, defining the aspects to be explored. And finally, the interpretation of the material based on the personal conceptions about the theme and theoretical reference based on the literature perspective that sustains the collaborative care from the intersectorality and the network care in mental health was carried out.

The research was approved by the Research Ethics Committee of the School of Nursing of the Federal University of Pelotas, under opinion No. 545.964/14 (CAAE: 27620714.2.0000.5316). The participants who agreed to take part in the study according to Resolution $466 / 12$ of the National Health Council were asked to sign the informed and free consent term.

\section{RESULTS AND DISCUSSION}

The results of this study were organized based on the theme "Challenges and possibilities for the construction of intersectoral networks", where issues based on potential possibilities that validate and/or qualify the care and impasses that are translated into encountered challenges were converged, which deserve greater investments to carry out territorial and networked care.

\section{Challenges and possibilities for building intersectoral networks}

The professionals approach the accomplishment of an integrated work, prioritizing that the care with the users is not restricted to the CAPCC, since this service needs to establish partnerships, both with other health services, as well as with services from other sectors:

We are always making visits, [...] every week a team leaves from here to visit the schools to check with the direction, what is the problem of that school [...] in the hospital to visit inpatients, take a look to see how they are to build the post-discharge bond, it is an important relationship to create bond during hospitalization or to rescue the lost bond [...] (PR15).

[...] "mais educação" \{federal project\} offers activities, theater, music, dance, and other devices that are not directly therapeutic, but may end up being so [...] I think it would be important to have therapeutic devices aimed at children 
and adolescents, as it has with adults, that could reduce the demand for referrals to specialized services, so sometimes they will be discharged from CAPCC, but there will also be no place to include activities that can be followed, with the same therapeutic look (PR18).

[...] in addition to the specialized services \{mental health\}, most basic units are with Family Health Strategies, with specialized FHS support, this is a privilege, [...] then the mental health network has been qualifying over time like any other network, the presence of both multidisciplinary and psychiatric residency, it has done something that is the dismantling of practices, that the services could rethink on their doing, a trigger for other mental health practices [...] (PR25).

Respondents PR15, PR18 and PR25 pointed out to the possibility of creating intersectoral networks in addition to specific mental health services, focusing on care in the area and in creating bonds. It is noted in the testimonies an extended clinical perspective, since child health care is only carried out if developed in an interdisciplinary way, as well as in the mobilization of its social and institutional environment (family, school, leisure spaces, services) $)^{(7)}$.

With this, they bring out the insertion of the residence program under the Multiprofessional and Psychiatric modality in the municipality, this integration between teaching and service, for the interviewees, besides qualifying the training of professionals, allows for building up collective actions that aim at the transformation of practices in health, and exchanging knowledge and experiences.

The interaction of the residents and workers that compose the service teams involved in the care of the child and adolescent population enriches the multiprofessional and interdisciplinary work, enabling new car forms, allowing still for the knowledge on the different professional groups to broaden the view on the population needs and, from this, collectively construct effective solutions for the unique situations ${ }^{(10)}$.

Another potentiality pointed out is the integration between the network and the mental health service, from the circulation of users in psychological distress through the various social and health spheres, being them, Basic Health Units (BHU) or Family Health Strategy (FHS), the Family Health Support Center (FHSC), or more community leisure spaces in the territory, thus broadening the view of the workers to care in the primary care, and in other services not those that are just specialized in mental health.

In this sense, a dynamic territory, where life creates and recreates itself, which is committed to the other, plus the articulation between services, sectors, people and policies, highlights intersectorality as a powerful strategy in the construction of actions and partnerships, to meet the complex dimensions of the individual under psychological distress beyond the care in the health axis ${ }^{(3)}$.

Although the researched professionals recognize potential factors for implementing intersectoral practices, they still see challenges as it is possible to observe in the following statements:

\section{[...] mental health is now in the process of bringing mental} health to basic care, getting people back to their homes, and the monitoring for the time needed. This is what we have been working on together, discussed with the CAPCC, thinking how we are going to do this movement (PR8).

[...] mental health until very recently was very limited to the CAPCC and today, they are returning to basic care [...] they (users) began to get discharge [...] hence one began to meet this demand, but nobody wanted this "they are crazy, they have to go to CAPCC" and it is not so, as they are from the territory (PR12).

[...] in addition to the CAPCC there are many other places to be, we do not want more to reproduce the institutionalization, we do not want people to come because they have nothing else to do, CAPCC is a place to be, it is a passage palace, and not a permanence place [...] beyond the open entrance door we want to open the exit door, so that people may understand that in a crisis they can come, occupy this space, but after this crisis passes over, they may return to occupy the space from where they came and the resources existing in those spaces, so today we are betting on this (PR25).

Although CAPCC is a strategic service in mental health care, this service is not recognized as the sole responsibility and nor should it be maintained for long-term follow-up. With this, the discharge process was cited as an alternative, allowing for strengthening care in other network areas, and a challenge, since it vivifies the transfer of the care for these individuals to other spaces.

The professionals PR8, PR12 and PR25 state that the care for these users in the CAPCC should be transient, which should exceed the specialized health sector, and move to the territory. However, they warn that planning the discharge process should happen in a multidisciplinary team, entering the primary health services, and the territory in order to guarantee care continuity and quality.

The concept on transference of mental health gives the idea of longitudinality, accountability and movement of the network as well as other territorial spaces such as the school, association of neighborhood residents, leisure 
spaces among others, and move to other possibilities of life ${ }^{(11)}$.

In PR12 and PR25 testimonies, it is noted that there is recognition and redirection of specialized out-of-service care, the return of Mental Health users to the Basic Care services, as well as signalizing the difficulty that the professionals often has to accept, welcome and be accountable for this public. However, they reveal that such articulation is possible and a necessary condition, since this user is from the territory.

The professionals in the study recognize the need to deinstitutionalize their ways of performing care actions, from the power of new forms of care offer beyond the protected area of the CAPCC signaling thus, the desire to deconstruct the care model centered on the disease and institutionalization. However, while recognizing the importance of support and articulated care between mental health and Basic Care, it is still a challenging task, since the logic of the work process developed by the health teams, especially for the child and adolescent in the basic care, is often limited to the curing character and sustained almost exclusively by the biomedical model.

Although it is a priority of the Basic Care services, health actions from a comprehensive care, are not enough to break with the instituted biomedical practice, so that these actions developed in the services still focus on programs and procedures following an outpatient model, centered on clinical and pharmacological care ${ }^{(12)}$. This is in line with the principles of health set up by the Unified Health System (Sistema Único de Saúde, SUS) and the Directives of Attention to Mental Health of Children and Adolescents, which directs health care beyond the clinical manifestation of the disease, but the unique understanding on this experience, that is to say, being a child/adolescent, having a family, living in a territory, having friends among other experiences that constitute them as people.

In addition, attention and understanding of the complexity involved in the care of children and adolescents with mental health problems is still a task under construction, which requires the need to understand the place of mental illness, the place of madness without reducing the individuals to specialties and pathologies. Perhaps this movement and the bet mentioned by these professionals to "open the door out" for the users to occupy other places and other spaces of the city, mental health may produce care beyond the psychic suffering, reaching the living territory, the circulation of users through the network services and consequently reaching social reintegration and reducing insanity's stigma.
In this study, the need for discussions about the therapeutic project, review and negotiation of such, and strengthening the co-responsibility among team, user and family in the construction of these projects also emerged, indicating the importance of constant dialogue among the teams, and evaluating new care demands and user autonomy. As the professional's narrative illustrates:

[...] we need to understand what the therapeutic project is and actually do in a way that the users may take part in such decision, on what will be proposed to them as care and that we have the responsibility to be reviewing periodically or as needed, [...] I think that what happens is that often a beautiful therapeutic project is built up together with the user, along with other sectors, but after that, we cannot review this project because we are not organized for this, so we are trying to find strategies to mange to review this (PR14).

The therapeutic design is a care plan and should be thought by professionals with active user participation, or as a guide to possible actions to think about the care and their movements in the network. However, there is a need to reflect and rethink about these offered actions, singularizing the care and mainstreaming the dynamics of the territory.

Therapeutic projects committed to the dimensions of psychosocial care must go beyond the CAPCC institution, they must set up solid relationships with the community, with the social and care network, deal with the singularities of the subjects and assume a critical posture of self-analysis, as they plan this, the professionals will be reflecting on their practice, and be included as protagonists (and not just spectators) in this process ${ }^{(13)}$.

In the excerpts from the interviews that follow in relation to the care provided to the child and adolescent population, it is focused on medical and psychological consultations, very restricted to specialized and individual care, causing them to have or believe that the only possibility for treatment is related to the clinical and specialized care.

[...] to discuss the outpatient clinic and the occupation of the territory are two strategies that we need to invest at the time and make a change in the service [...] so the big challenge is this, the ambulatory, because there are other ways of working, when I say ambulatory I mean individual care for specific professionals [...], and with each of those qualified professionals that exist there are a number of possibilities, they need to be able to authorize themselves, have autonomy to think different things to do within the service [...], occupy other spaces, [...] find a community hall to make a group, make a workshop [...] (PR14). 
$[. .$.$] the services are focused on the medical consultation,$ focused on the knowledge on psychology, on the CAPCC the very question is of pedagogy, at last very focused on professions and not the issue of collective health, more comprehensive care, but this is also a talking movement, the services were very closed [...] now the workers are in the units and are reviewing their practices [...] if it is to work in a network, this has to be by talking, so we are trying to open some channels for this to take effect, but also that everybody shall be doing their work, our care [...] (PR21).

From the testimonies of PR14 and PRI21, it is observed that the interdisciplinary work is difficult to carry out, and that the culture of the medical-hegemonic model prevails in comparison to the psychosocial and intersectoral mode, whose forms of care must excel those of the medicalization and psychologist-centered care, in order to encompass therapeutic interventions of shared care, with co-responsibility among the various sectors and professions.

Thus, it is fundamental to deconstruct the specialist discourse, that is, related to the "pathologization, therapeutization, medicalization, psychologization", since this logic reduces and individualizes, besides disregarding bio-psychosocial factors. The concern with the ambulatory functioning that privileges the individual clinical model in the care of the child and adolescent population evidenced by the researched professionals, reveals the difficulties of the team in performing a collective internally work and with each other.

The care under the bias of the outpatient logic mentioned by the participants corroborates with a study that alerts to the large number of children diagnosed with some type of psychic suffering and the psychiatry-related discourse, a social trend for framing the diagnosis, specialized and pharmacological therapy without an analysis of what this situation can cause in the development of these subjects. They also point out that when the treatment is restricted to practice such as these ones, the right of the child and adolescent to develop their social role is removed in order to assume the identity of the insane or the sick reinforcing the admission to mental asylum, since the individual is not enclosed in an institution, but yes in their own label ${ }^{(14)}$.

The psychiatric reform initiated questions and recommendations about other treatment devices, thus, rather than constantly analyzing the micro-politics in the daily work of the teams and their confrontations with the clinic, it is essential to evaluate and minimize the homogenization characteristic of the traditional, crystallized and centered model as well as in the field of medical professional knowledge or other specialist ${ }^{(15)}$.
Regarding the challenges, the statements below point out not only to the importance of effective public policies, but also to access and partnership with other community spaces, especially the adolescent population, recognizing that the actions should consider the triad on housing, work and recreation.

[...] it is still a challenge to have effective public policies regarding children and adolescents, [...] policies of coexistence, leisure spaces, being able to think on structures of the city more focused on this population, also on the teenager being able to join the services, in other spaces, to think about that phase (adolescence), I think the health service is also not prepared to care for the adolescent, and it needs a lot of qualification [...] (PR20).

[...] they (adolescents) need other opportunities, to work in the supermarket, if they could do packing workshops, they could have other visions, to work in a flower shop, [...] that they had other programs that could develop their abilities I think this is still lacking (PR24).

For the child and adolescent care, in addition to building networks, work must be developed that brings out policies closer to the community life and services, extending to the various territorial resources, citizenship, leisure and sports, such as coexistence, clubs, among others. In this way, consider children and adolescents not only as part of political-ideological projects to be inserted in the territory, but rather that other spaces of care and attention that promote health, autonomy and increased social participation may be recognized and guaranteed ${ }^{(16)}$.

Another challenge mentioned is the difficulty for approaching the family in the care, as illustrated in the following statements:

[...] the family tries to delegate to school and if you do not call, so that the family may take part [...]. When I say family I speak generally, sometimes a parent, two parents three parents go, but in general they are accommodated, I see the family as accommodated and very often you call, and they do not attend. We have had cases that we had to go to the family home because we called once, twice, three times and they did not come and we went after them, in the house [...] (PR5).

As I see it, there is no way of thinking about making an intervention with the child alone without considering the relative and building up together [...] working how each one will do their part, in resolving the situation depending on each case [...] I think that the family participation is fundamental (PR8). 
[...] nowadays, families are delegating much of the education of their children to school, and they are not doing their homework, which is putting limits, teaching principles and this ends up reflecting in the reality that we have, whenever this is transferred to another one [...] there are people who come here saying that they want to give their son to the promoter because they can no longer put limits, just to get an idea [...] (PR22).

Professionals PR5, PR8 and PR22 consider that including the family in the treatment is still a challenge, and recognize that, for creating more effective care projects, it is necessary to consider and guarantee a greater involvement of these families, as well as their opinions, anguishes and doubts.

These statements provoke the reflection that the care of the child and the adolescent in mental health cannot be separated from the family, just as family interaction absence interferes in the treatment for this population. In this sense, the family becomes an indispensable element in the care of its members, especially when these individuals are children and adolescents and have greater affective, social and economic dependence.

In this context, the family or caregiver are important collaborators and can contribute significantly to the success of the treatment, if involved in the care process ${ }^{(17)}$. Although there is consensus about their active role in the co-construction of care, it is necessary to point out that absence or distance from family cooperation in the care may have negative impacts on the therapy and how they experience the suffering of children and adolescents.

The participation of the family in the care of people with psychic suffering is fundamental. However, a study on care interventions in childhood and adolescence showed that the family was unable to meet all of the child's demands at times, showing stressful relationships due to expectations, feelings of frustration and guilt. In this way, network services available in the territory prove to be an important support source for these relatives ${ }^{(18)}$.

Corroborating with the discussions herein submitted and highlighting the need for studies in relation to the public served by the CAPCC with the other services, a survey carried out on the articulations between the FHS and CAPCC teams, pointed out the commitment of the teams to work in network, performing partnerships with the community resources, even when scarce. They portrayed the traditional model still in effect for care as an obstacle to be overcome, even when the mode of psychosocial attention of care is preconized, and contrary to the fragmented way of seeing and treating the subject ${ }^{(7)}$.
Also, in this theme's scope, in another experience that evaluated the articulation between the mental health service to the child and the adolescent and FHS, facilitating actions and barriers to collaborative care, there was identified as a difficulty the lack of knowledge about resources in the territory, and facilitating factors, collaborative care among the services was recognized as a strategy to qualify mental health for children and adolescents ${ }^{(19)}$. This analysis is in line with the results found in this research, especially when it recognizes that intersectoral actions developed among institutions, sectors and actors allow for developing more creative and effective possibilities for the care.

The data in this study also corroborate with another study about the articulation of the child and adolescent CAPCC with the devices found in the care network and the education sector, showing that the school is perceived by the professionals as a fundamental component, which requires a greater investment of partnership by part of the mental health team. The professionals also criticized the medicalization and pathologization of childhood requesting constant questioning and revision for the deconstruction of this type of conduct. As well as they are advocating on using the community spaces, with a view to promoting activities that recognize that not all problems should or can be reduced to biological or diagnostic issues ${ }^{(20)}$.

Although an ideal care network is made up by the health services, sectors and resources of the territory, and the sharing of responsibilities and actions just happen if they are mainstreamed by workers and services. That is, "it depends (and builds on) the people who act in the services, the connections and bonds that they establish with each other to achieve a common goal"(7:363).

Therefore, it is important to problematize with the professionals about actions carried out within the specialized services and with the environment. The workers of the services involved in the care for the child and the adolescent for mental health, from reflection processes, and discussion, can evaluate their work process, as well as, bring out the limitations and the outputs to a model of mental health compatible with the psychosocial mode.

\section{口INAL CONSIDERATIONS}

This study aimed to analyze the possibilities and challenges in building up intersectoral networks in mental health for children and adolescents. Child and adolescent care raised to the intersectoral plan is a necessity and a recommendation for the public mental health policies.

The articulation between the different levels that compose the network for care in mental health added to the 
devices of the territory strengthen the work in network and the model for psychosocial care, since they consider the collective commitment and the deconstruction of an exclusively specialized care. Thus, the CAPCC ceases to be "the service for psychic care", to be "one more service" that makes up the network, but not the only one for the place of treatment.

In this direction, the results in this study, regarding the possible actions that configured potential possibilities for intersectoral care in childhood and adolescence, included the articulation of different devices such as basic care, the secretary of health and social assistance together with the school; the importance on knowing the context of the users with home visits and the need for intersectoral actions with different professionals that work the insertion and activities with the users in their community.

The participants demonstrated a commitment to an interdisciplinary and articulated work, but highlighted challenges to be overcome for effective intersectoral work. They pointed out the structural revision and understanding about the therapeutic projects identified as an important tool to get to know the subjects and propose care based on their needs, triggering points of the network and calling for shared and co-responsible care.

The difficulty for linking the family to the treatment was another mentioned challenge, stating that the collaborative role of family members in treating the user is fundamental, but this does not always happen, especially when the responsibility is transferred to the service team. These difficulties with relatives may be understandable since, historically, they have remained isolated from this demand. With this, it fits here to reflect on how to create strategies to approach such relatives, assisting them in the agreement on the psychic suffering as part of their routines and empowering them to feel capable to deal with the conflicting and stigmatizing situations.

The participants also identified the need to review the inner service organization, which is focused on a biologic-related model, linked to the diagnosis, pathology, individual and specialized care, that is, centered on the professional, whether a physician, psychologist or pedagogue. This complicates and compromises the implementation of joint interventions and the development of mainstream therapeutic projects. In spite of this fragmentation to be overcome, it is important to emphasize that it impedes the power of the joint work and the concretization of the extended care.

Lastly, it is necessary to deepen the debate on the care for the child and adolescent public, since it is a group that requires discussion, problematization and studies in relation to the care network and its complexities. Regarding the limitations, we emphasize the accomplishment of this research from a single child and adolescent mental health service and its intersectoral network, allowing for displaying the results only for a local context and focus only for the professionals involved in the care actions.

Therefore, for future researches, it is recommended to carry out other researches problematizing the care network of the child and adolescent in the territorial and intransectoral perspective in order to achieve new perspectives on the care and its articulations for consolidating the Mental Health policy of the Child and Adolescent.

\section{REFERENCES}

1. Braga CP, D`Oliveira AFPL. Políticas públicas na atenção à saúde mental de crianças e adolescentes: percurso histórico e caminhos de participação. Ciênc Saúde Coletiva. 2019;24(2):401-10. doi: https://doi.org/10.1590/141381232018242.30582016

2. Couto MCV, Delgado PGG. Crianças e adolescentes na agenda política da saúde mental brasileira: inclusão tardia, desafios atuais. Psic Clin. 2015;27(1):17-40. doi: https://doi.org/10.1590/0103-56652015000100002

3. Olschowsky A, Wetzel C, Schneider JF, Pinho LB, Camatta MW. Avaliação das parcerias intersetoriais em saúde mental na estratégia saúde da família. Texto Contexto Enferm. 2014;23(3):591-9. doi: https://doi.org/10.1590/010407072014001970012

4. Romagnoli RC, Amorim AKMA, Severo AKS, Nobre MT. Intersetorialidade em saúde mental: tensões e desafios em cidades do sudeste e nordeste brasileiro. Revista Subjetividades. 2017;17(3):157-68. doi: https://doi. org/10.5020/23590777.rs.v17i3.6075

5. Lima RC, Carvalho MCDA, Silva PRFD. Saúde mental na infância e adolescência. In: Jorge MAS, Carvalho MCA, Silva PRF, orgs. Políticas e cuidado em saúde mental: contribuições para a prática profissional. Rio de Janeiro: Fiocruz; 2014. p. 229-54.

6. Zaniani EJM, Luzio CA. A intersetorialidade nas publicações acerca do Centro de Atenção Psicossocial Infantojuvenil. Psicologia em Revista, 2014;20(1):56-77. doi: https://doi.org/10.5752/P.1678-9523.2014V20N1P56

7. Delfini PSS, Bastos IT, Reis AOA. Peregrinação familiar: a busca por cuidado em saúde mental infantil. Cad Saúde Pública. 2017;33(12):e00145816. doi: https:// doi.org/10.1590/0102-311x00145816

8. Damari B, Alikhani S, Akrami F. Analysis of Iranian youth health policy: necessity of action-oriented interventions. Int J Prev Med. 2018;9:39. doi: https://doi. org/10.4103/ijpvm.IJPVM_341_16

9. Minayo MCS. 0 desafio do conhecimento: pesquisa qualitativa em saúde. 14. ed. São Paulo: Hucitec; 2014.

10. Fernandes MNS, Beck CLC, Weiller TH, Viero V, Freitas PH, Prestes FC. Suffering and pleasure in the process of forming multidisciplinary health residents. Rev Gaúcha Enferm. 2015;36(4):90-7. doi: https://doi.org/10.1590/19831447.2015.04.50300

11. Guedes AC, Olschowsky A, Kantorski LP, Antonacci MH. Transferência de cuidados: processo de alta dos usuários de um centro de atenção psicossocial. Rev Eletr Enf. 2017;19:a42. doi: http://doi.org/10.5216/ree.v19.43794

12. Batista KA, Oliveira PRS. A saúde mental infantil na atenção primária: reflexões 
acerca das práticas de cuidado desenvolvidas no município de Horizonte - CE. Pesqui Prát Psicossociais. 2018 [cited 2018 Sep 10];12(3):1-17. Available from: http://pepsic.bvsalud.org/scielo.php?script=sci_arttext\&pid $=$ S1809-89082018000100006

13. Vasconcelos MGF, Jorge MSB, Catrib AMF, Bezerra IC, Franco TB. Therapeutic design in Mental Health: practices and procedures in dimensions constituents of psychosocial care. Interface (Botucatu). 2016;20(57):313-23. doi: https://doi. org/10.1590/1807-57622015.0231

14. Belotti M, Maia CC, Avellar LZ, Silva POM. Concepções de profissionais de saúde sobre as atribuições de um centro de atenção psicossocial infanto-juvenil. Psic Teor Pesq. 2018;34:e34430. doi: https://doi.org/10.1590/0102.3772e34430

15. Rinaldi DL. Micropolítica do desejo: a clínica do sujeito na instituição de saúde mental. Ciênc Saúde Coletiva, 2015; 20(2):315-23. doi: https://doi. org/10.1590/1413-81232015202.17332013

16. Taño BL, Matsukura TS. Saúde mental infantojuvenil e desafios do campo: reflexões a partir do percurso histórico. Cad Ter Ocup UFSCar. 2015;23(2):43947. doi: https://doi.org/10.4322/0104-4931.ctoAR0479
17. Noronha AA, Folle D, Guimarães AN, Brum MLB, Schneider JF, Motta MGC. Perceptions of adolescents' family members about therapeutic workshops in a child psychosocial care center. Rev Gaúcha Enferm. 2016; 37(4):e56061. doi: https://doi.org/10.1590/1983-1447.2016.04.56061

18. Tszesnioski LC, Nóbrega KBG, Lima MLLT, Facundes VLD. Construindo a rede de cuidados em saúde mental infantojuvenil: intervenções no território. Ciênc Saúde Coletiva. 2015; 20(2):363-70. doi: https://doi.org/10.1590/141381232015202.05082014

19. Teixeira MR, Couto MCV, Delgado PGG. Atenção básica e o cuidado colaborativo na atenção psicossocial de crianças e adolescentes: facilitadores e barreiras. Ciênc Saúde Coletiva. 2017 June;22(6):1933-42. doi: https://doi.org/10.1590/141381232017226.06892016

20. Duarte KL, Souza EM, Rodrigues L. [Importance and challenges of networking between the school and a Brazilian juvenile mental health service]. J Child Adolesc Psychol. 2017 [cited 2018 Sep 20];8(1):155-71. Portuguese. Available from: http://revistas.lis.ulusiada.pt/index.php/rpca/article/view/2484
Corresponding author:

Cristiane Kenes Nunes

E-mail: criskenes@gmail.com
Received: 11.11.2018

Approved: 06.27.2019 


\section{ERRATUM}

In the title of the article "Mental health in children and adolescents: cision of the professionals on challenges and possibilities in building up intersectoral networks", with elocation e20180432 and number DOI: 10.1590/1983-1447.2019.20180432, published in journal Revista Gaúcha de Enfermagem, from the year 2019, volume 40,

Where it was written:

Mental health in children and adolescents: cision of the professionals on...

Should read:

Mental health in children and adolescents: vision of the professionals on...

\section{(cc) BY-NC}

